Article

\title{
Intellectual Capital as a Factor of Sustainable Regional Competitiveness
}

\author{
Virginija Januškaitė * and Lina Užienè \\ School of Economics and Business, Kaunas University of Technology, 44249 Kaunas, Lithuania; \\ lina.uziene@ktu.lt \\ * Correspondence: virginija.januskaite@ktu.edu; Tel.: +370-641-06371
}

Received: 9 November 2018; Accepted: 14 December 2018; Published: 19 December 2018

\begin{abstract}
Sustainable competitive advantage is a widely explored topic at the organizational level. Although, regions care about competitiveness as much as organizations, because it leads to improved welfare and economic performance. However, sustainable regional competitiveness is still an ambiguous concept. On the one hand, it considers long lasting economic growth and on the other hand, it focuses on the sustainability and well-being of upcoming generations. This paper considers both aspects. Intellectual capital, considered to be the foundation for competitive growth, is selected as a basis for the analysis. It is evaluated as a factor involved in regional competitiveness. Sustainable regional competitiveness in this paper is defined based on the World Economic Forum framework, the Global Sustainable Competitiveness Index, and the Global Green Economy Index. The aim of the paper is to identify the interlinks between intellectual capital and sustainable regional competitiveness. The paper is based on a literature review and index analysis. The findings show that intellectual capital is involved in almost all factors influencing regional competitiveness and it is even more important for sustainable regional competitiveness. It can be concluded that the interlinks between intellectual capital and sustainable regional competitiveness are strong and inseparable.
\end{abstract}

Keywords: Intellectual capital; regional competitiveness; sustainable regional competitiveness; regional development

\section{Introduction}

Competitiveness is today's most popular slogan and aspiration of nations, regions, cities, organizations, and even people. We all compete in the global market and look for our place in this vast world. However, the true meaning behind the concept of competitiveness is still not fully understood. Different authors and organizations define competitiveness in different ways [1-3] and this leads to the meaning getting lost between the lines. Is competitiveness defined through GDP (Gross Domestic Product) or other financial indicators? Or is competitiveness defined through well-being and better life quality? The answer is somewhere between these two. Developed countries are increasingly concerned about sustainability and the future of the next generations (e.g., Sweden, Norway, Iceland, Finland, Denmark etc [4]. Whereas underdeveloped countries seek for today's success and better life in the present. So, where should we focus on? It seems that the focus depends on what we are looking for.

Competitiveness is believed to bring a better life in the future. However, the future is dependent on activities carried out today. Therefore, sustainability must be considered to ensure tomorrow comes and is not worse than yesterday. Sustainable development is a key to future competitiveness and ensures that society's present needs do not contradict the needs of future generations [5]. Therefore, currently, in terms of competitiveness, we must shift our mental understanding towards sustainable competitiveness, even though it is still not perceived fully. In this paper, we aim to define this concept based on three frameworks: The World Economic Forum framework, the Global Sustainable 
Competitiveness Index, and the Global Green Economy Index, and to relate it to the intellectual capital concept.

Regional dimension nowadays becomes increasingly important because even in the same country, a certain level of differentiation may be observed. Some regions lag while others thrive. The European Commission has already noticed this fluctuation and has initiated monitoring of regional innovativeness and competitiveness to shape particular regional policy making, which would lead to the catching up of lagging regions and improvement of overall national competitiveness [6]. In addition, the organizational level is explored much more thoroughly and answers to sustainable competitive advantage may be captured from the past research [7-9]. Therefore, in this paper, a focus on the regional dimension is more relevant than the national or organizational dimension.

Regional competitiveness in this paper is analysed in the light of intellectual capital (IC) theory. It is believed that intellectual capital is a foundation for the future growth and wealth of regions [10-13]. Traditionally, it is divided into three dimensions of human, structural, and relational capital [9]. All these three dimensions are required for sustained regional growth. They interrelate and only the certain composition embedded in the regional context can create a competitive advantage for a region.

This paper is focused on analysing regional intellectual capital in the context of regional competitiveness to explain the relations between these concepts. The main scientific contribution of the paper is it attempts to define sustainable regional competitiveness and to capture interlinks between IC and this concept as well as explain how regional competitiveness is related to sustainability. Paper begins with an analysis of the theoretical background. The theoretical background is divided into three subchapters: (1) "Regional competitiveness", which outlines major definitions (the Global Competitiveness Report, European Competitiveness Report) and accepted concepts of competitiveness; (2) "towards sustainable regional competitiveness" provides systematic analysis of the three sustainable regional competitiveness frameworks; and the (3) "regional intellectual capital framework" provides a literature review of the most influential authors in the field and describes six different approaches to measure regional intellectual capital. Then, factors influencing regional competitiveness are defined, the later intellectual capital role in sustainable regional competitiveness is discussed, and, finally, a discussion and conclusions are provided. The paper finishes with research limitations and future research recommendations.

\section{Methodology}

This paper is based on a systematic literature review of intellectual capital papers, competitiveness literature, and three sustainable competitiveness frameworks to define sustainable regional competitiveness. The research carried out was qualitative in nature. The theoretical background is divided into three subchapters, which provide the main theoretical knowledge relevant for the research. Systematic analysis of the World Economic Forum sustainable development framework, the Global Sustainable Competitiveness Index, and the Global Green Economy Index leads to the exclusion of the main five dimensions of sustainable regional competitiveness presented in chapter 5 . An analysis of the regional intellectual capital framework leads to a definition of regional intellectual capital. In chapter 3 subchapter 3, the conceptual relations between IC, regional competitiveness, and sustainable regional competitiveness are provided in Figure 1. Later, in chapter 4, a systematic analysis of factors influencing regional competitiveness is provided. Research papers and books were analyzed searching for different factors. The search was finished when factors started to repeat themselves. Intellectual capital as an associated factor was drawn from qualitative assessment of the regional intellectual capital definition provided in chapter 3, subchapter 3. Chapter 4 represents the interlink between regional competitiveness and intellectual capital. In this chapter, competitiveness is interpreted as a common understanding and concept presented in chapter 3 , subchapter 1 , which defines sustainable competitiveness only as long term competitiveness. Chapter 5 concludes and defines sustainable regional competitiveness based on the analysis in chapter 3, subchapter 2 , which enriches the concept with sustainability dimensions. Interlinks between intellectual capital and 
sustainable regional competitiveness are based on qualitative judgement and the concept of IC as well as previous works in this field [14-17].

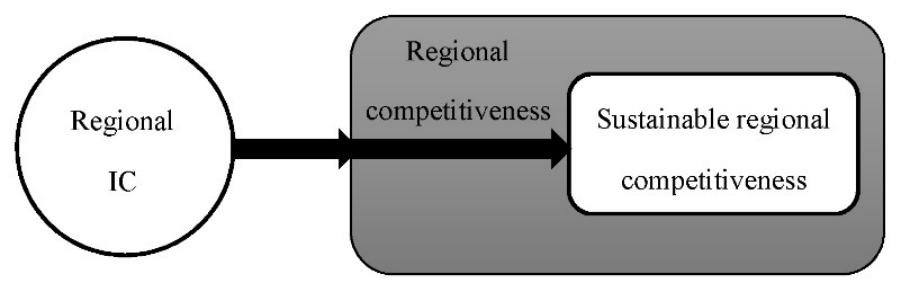

Figure 1. Relation between IC (Intellectual Capital), regional competitiveness, and sustainable regional competitiveness (edited by authors).

\section{Theoretical Background}

\subsection{Regional Competitiveness}

Wealth, prosperity, and economic growth are usually named as outcomes of substantial and well-developed intellectual capital. Such a viewpoint has led to research demonstrating IC's relation to GDP. However, GDP has become a questionable indicator of prosperity and even economic development. Henderson [1] reveals that society defines national wellbeing beyond GDP. Makarov [14] also agrees that the account of GDP is unsuccessful. Delgado et al. [2] claims that the USA and many other policy makers consider competitiveness as the most important factor of national economic policy. However, competitiveness is a multisided concept at the national level. The World Economic Forum [3] in the Global Competitiveness Report 2014-2015 states that for robust economic growth, inclusive economies, productivity, and well-functioning markets are required. The concept of national competitiveness covers these aspirations. National competitiveness is defined as the set of institutions, policies, and factors that determine the level of productivity of a country [3]. Delgado et al. [2] define competitiveness as the expected level of output per working-age individual given the overall quality of a country as a place to do business. The European Commission states that competitiveness refers to the overall economic performance of a nation measured in terms of its ability to provide its citizens with growing living standards on a sustainable basis and broad access for jobs to those willing to work [18]. In the European Competitiveness Report 2009 [18], it is further explained that at the very roots of competitiveness, lies macroeconomic and institutional arrangements that shape the environment under which businesses act and individual creativity as well as effort are rewarded. This means that competitiveness can be interpreted in terms of performance, which is expressed through the GDP and industrial performance of a country or it can be interpreted in terms of empowering the environment for business to thrive. Since policy making implications are desired outcomes of IC measurements, they must provide information on how IC affects the business environment and how it can be improved through IC development. Therefore, definitions of national competitiveness disclose a necessity to focus more on conditions and the environment empowering economic growth rather than the final result, which is demonstrated by the GDP.

\subsection{Towards Sustainable Regional Competitiveness}

Regional competitiveness today has become inseparable from the sustainable development paradigm. Sustainable development was defined in the report, "Our Common Future", as the "development that meets the needs of the present without compromising the ability of future generations to meet their own needs" [5]. A long term competitive advantage may not be achieved without thinking about the future and the needs of our descendants. In the Global Competitiveness Report (2013-2014) [19], the World Economic Forum assessed the sustainable competitiveness of nations. In this report, it attempted to relate the competitiveness of nations with sustainability. Economic development should go hand in hand not only with environmental sustainability, but also with a social dimension. Therefore, the World Economic Forum [19] produced the definition of 
sustainable competitiveness as "the set of institutions, policies, and factors that make a nation remain productive over the longer term while ensuring social and environmental sustainability." From this definition three dimensions can be excluded: Competitiveness, social sustainability, and environmental sustainability, which, all together, create sustainable regional competitiveness.

For a long time, it was considered that competitiveness and environmental sustainability cannot work together, as natural resources are limited and industrial production creates waste and pollution. However, with innovation and new clean manufacturing technologies, this situation has changed and now industrial production may grow without damaging the environment as much as it used to. The World Economic Forum [19] associates competitiveness and environmental sustainability in three dimensions: (1) Efficient use of natural resources; (2) improved health; and (3) biodiversity for innovation. Green economies tend to perform better in terms of labour health (decreased pollution), innovation, and restoration of natural capital. Such economies last longer compared to "brown" economies, which "underinvest in natural capital and overinvests in activities that cause its degradation" [19].

Social sustainability is described as a lack of distortion between the poorest and the wealthiest. Environmental sustainability and social sustainability go hand in hand, ensuring that every member of the community has access to the necessary resources. The World Economic Forum [19] relates environmental sustainability with social sustainability in five dimensions: (1) Health and environmental degradation; (2) demography, poverty, and the environment; (3) energy and social stability; (4) climate change, food security, and conflict; and (5) climate change and women's empowerment. An overall framework of sustainable regional competitiveness according to the World Economic Forum is shown in Table 1.

The Global Sustainable Competitiveness Index by SolAbility [4] has a different framework to explore sustainable competitiveness. GDP, as an indicator to measure the well-being of people, is criticized, stating that even though GDP is growing, it does not mean that society is doing better. Additional dimensions are required to measure the real status of social well-being rather than relying on a single indicator, such as the GDP. The Global Sustainable Competitiveness Index is provided as "a thorough alternative to the GDP to measure the real wealth of nations, and to express the potential for sustain current wealth levels" [4]. This index is comprised from pillars that are claimed to be the foundation for sustained growth and future wealth: Natural capital availability; national governance efficiency (the framework in which all players operate-the outcomes of policy directions and investments, e.g., the availability of infrastructure); intellectual capital (innovation and business capabilities); resource efficiency; and social cohesion. The Global Sustainable Competitiveness Index framework is shown in Table 2.

"The Global Sustainable Competitiveness Index (GSCI) is a measurement for social, environmental, and economic development" [4]. The similarity to the framework of the World Economic Forum should be noted. This shows that economic development is inseparable from environmental and social issues, which must be addressed together. In the GSCI, it is emphasized that current competitiveness measurement methods based on only financial indicators and GDP reflects only today's success, but do not say anything about the future. Business may flourish only in an environment that is sustainable and able to provide long-term resources as well as a high level of social development, which includes education, infrastructure, and societal framework.

The Global Green Economy Index (GGEI) developed by Dual Citizen LLC (Limited Liability Company) [20] is another alternative framework to measure the performance of nations in the long term. The GGEI is a well-known and widely accepted index to benchmark countries in respect to sustainable development and emission reduction. It is based on four key dimensions: (1) Leadership and climate change; (2) efficiency sectors; (3) markets and investment; and (4) the environment. The GGEI emphasizes the role of national governments as leaders and initiators of the green movement. They have power to communicate and promote green investments and sustainable industrial development. Buildings, transportation, energy, and tourism are also covered in the GGEI. Clean transportation and 
renewable energy utilization may lead to lower emissions and a cleaner environment. Sustainable tourism is an exceptional dimension in this index. No other previously mentioned indexes have analysed sustainable tourism. The market and investment dimension explores investments in renewable energy, clean innovations, and corporate sustainability. The main emphasis in this index is dedicated to the government's role as a promoter and catalyst for sustainable development. The GGEI framework is shown in Table 3.

All three approaches capturing sustainable competitiveness have some aspects in common. All of them agree that economic development should not deteriorate environmental and social well-being. The concept of competitiveness is changing and it should be overlooked through the new light of sustainability. The concept of sustainable regional competitiveness based on the analysis in this subchapter can be defined through these five dimensions: Environmental sustainability; social sustainability; government; infrastructure efficiency; and investments and technology. 
Table 1. Sustainable regional competitiveness according the World Economic Forum [19] (edited by authors).

\begin{tabular}{|c|c|c|}
\hline \multicolumn{3}{|c|}{ Sustainable Regional Competitiveness } \\
\hline Economic Sustainability & Environmental Sustainability & Social Sustainability \\
\hline Public_-private collaboration; & $\begin{array}{l}\text { Efficient use of natural resources; } \\
\text { improved health; and } \\
\text { biodiversity for innovation. }\end{array}$ & $\begin{array}{l}\text { Health and environmental degradation; } \\
\text { demography, poverty, and the environment; } \\
\text { energy and social stability; } \\
\text { climate change, food security, and conflict; and climate change } \\
\text { and women's empowerment. }\end{array}$ \\
\hline
\end{tabular}

Table 2. The Global Sustainable Competitiveness Index framework [4] (edited by authors).

\begin{tabular}{clll}
\hline & \multicolumn{1}{c}{ The Global Sustainable Competitiveness Index } \\
\hline \multicolumn{1}{c}{ Natural Capital } & \multicolumn{1}{c}{ Sosial Capital } & \multicolumn{1}{c}{ Intellectual Capital } \\
\hline $\begin{array}{l}\text { The given natural environment, } \\
\text { including the availability of } \\
\text { resources, and the level of the } \\
\text { depletion of those resources. }\end{array}$ & $\begin{array}{l}\text { Health, security, freedom, } \\
\text { equality, and life satisfaction } \\
\text { within a country. }\end{array}$ & $\begin{array}{l}\text { The efficiency of using available } \\
\text { resources a measurement of } \\
\text { operational competitiveness in a } \\
\text { resource-constrained world. }\end{array}$ & $\begin{array}{l}\text { The capability to generate wealth and } \\
\text { jobs through innovation and } \\
\text { value-added industries in the } \\
\text { globalised markets. }\end{array}$ \\
\hline
\end{tabular}

Table 3. The Global Green Economy Index framework [20] (edited by authors).

\begin{tabular}{|c|c|c|c|}
\hline \multicolumn{4}{|c|}{ The Global Green Economy Index } \\
\hline Leadership \& Climate Change & Efficiency Sectors & Markets \& Investment & Environment \\
\hline $\begin{array}{l}\text { Climate change performance; } \\
\text { international climate forums; } \\
\text { head of state; } \\
\text { media coverage. }\end{array}$ & $\begin{array}{l}\text { Buildings; } \\
\text { transport; } \\
\text { tourism; } \\
\text { energy; } \\
\text { resource efficiency. }\end{array}$ & $\begin{array}{l}\text { Renewable energy investment; } \\
\text { cleantech innovation; } \\
\text { corporate sustainability; } \\
\text { green investment promotion and facilitation. }\end{array}$ & $\begin{array}{l}\text { Agriculture, air quality, water resources, } \\
\text { water and sanitation, biodiversity and } \\
\text { habitat, fisheries and forests. }\end{array}$ \\
\hline
\end{tabular}




\subsection{Regional Intellectual Capital Framework}

The regional intellectual capital framework has a lot of similarities to the national IC framework, but even though they have some aspects in common, they are not the same. It is usually assumed that the most important intellectual resources are those that contribute to the creation of a competitive advantage and so result in an improved economic situation of a region. It is not easy to define that contribution without relating it to the creation of a competitive advantage. However, it is widely adopted that intellectual capital, which is defined as a hidden value of individuals, organizations, institutions, and communities in a region or a nation, is the foundation of national and regional wealth and potential growth in the future [10-13]. Intellectual capital is a theory that has existed for more than 20 years, but regional and national levels are still poorly explored [21]. The national level is explored more thoroughly, and both regional and national frameworks will be discussed in this chapter.

The definition of intellectual capital at the regional and national levels is broad and complex, leaving a lot of freedom to interpret it from different perspectives. Käpylä [21] points that such indeterminacy leads to the exclusion of certain knowledge, like ethics, culture, history etc., from measurement indexes, resulting in easily measurable indicators that may not fully reflect regional intellectual capital. Some researchers who have introduced national intellectual capital benchmarking indexes highlight that the supply of indicators is limited and a fraction of intellectual capital is left unmeasured [11,22]. Different national intellectual indexes (National Intellectual Capital Index (NICI), Intellectual Capital Index (ICI), Intellectual Capital Monitor (ICM), National intellectual capital indices for 40 countries (NICI40), ELSS (refers to Edvinsson, Lin, Ståhle and Ståhle), etc.) include different indicators as well as different intellectual capital categorisations and it is not known which interpretation is the best one. Usually, benchmarking is applied for diagnostic purposes [11,12,22-24]. However, the relevancy of the information provided by benchmarking methods is questionable [25]. Therefore, regional dimension approaches seek to find a better way to capture intellectual capital and utilize it for regional needs.

The issue of the uniqueness of intangible resources is an additional concern. Uniqueness and the contextual situation is significantly stressed at the organizational level by Chaminade and Johanson [26] and Angel and Ortiz [27]. However, Schiuma et al. [13], Kujansivu [28], and Lönnqvist et al. [29] accept this to be true at the national level as well. Certain research has emphasized that intangible resources are unique for a particular country and uniqueness must be considered when evaluating intellectual capital [21,30-33]. Käpylä et al. [33] points out that national development objectives differ in addition to the national context. It is not hard to understand that the regional dimension faces the same problem. Every region is unique, with unique resources and a particular context. Hence, intellectual capital measurement methods must address this problem and provide a way to take uniqueness into account.

Regional intellectual capital approaches are more target oriented perspectives, which take into consideration regional development objectives and demonstrate a better orientation to practice [13,30,34-37]. Regional competitiveness becomes a major focus of this approach [34,35,38]. Categorisation of regional intellectual capital becomes based on the desired outcome or aspiration, for instance: Sustainability [34], sustainable economic development [38], social wellbeing [36], and competitive development [35] (see Table 4). Kozak [39] developed a framework for regional intellectual capital management in respect to specific strategic objectives. However, the framework is not approved yet. Nevertheless, an orientation to regional objectives, competitiveness as well as intellectual capital interpretation, and an evaluation taking into consideration a region's contextual situation is needed in practice. Even though different intellectual capital dimensions are encountered in measurement frameworks, the most common categorisation is human, structural, and relational capital. In this paper, this categorisation is referred to as well. 
Table 4. Regional intellectual capital approaches (edited by authors).

\begin{tabular}{|c|c|c|}
\hline Authors & Regional Development Goal & Intellectual Capital Dimensions \\
\hline Rodriguez and Viedma Martí [38] & $\begin{array}{l}\text { Sustainable economic } \\
\text { development }\end{array}$ & $\begin{array}{l}\text { Institutions and governance } \\
\text { Societal framework } \\
\text { Social capital } \\
\text { Technology } \\
\text { Regional human capital }\end{array}$ \\
\hline Medina et al. [34] & Sustainability & $\begin{array}{l}\text { Training and development } \\
\text { Public administration } \\
\text { Social capital } \\
\text { Environmental capital } \\
\text { Tourism capital } \\
\text { Economic activity }\end{array}$ \\
\hline Lerro and Schiuma [35] & Competitive development & $\begin{array}{l}\text { Human capital } \\
\text { Structural capital } \\
\text { Relational capital }\end{array}$ \\
\hline Lönnqvist et al. [36] & Social wellbeing & $\begin{array}{l}\text { No dimensions excluded. Used } \\
\text { indicators: } \\
\text { Diversity of the region: Manifold } \\
\text { knowledge } \\
\text { Educations } \\
\text { Universities } \\
\text { Vitality that universities and the } \\
\text { youth bring } \\
\text { Very good regional image } \\
\text { Capability for renewal } \\
\text { Strong and varied competence of } \\
\text { regional actors } \\
\text { Good-open and } \\
\text { trusting-relational actors } \\
\text { Congenial atmosphere: } \\
\text { willingness to seek consensus and } \\
\text { reconciliation } \\
\text { Eagerness for future-oriented } \\
\text { development }\end{array}$ \\
\hline Yigitcanlar et al. [40] & Knowledge-based development & $\begin{array}{l}\text { Human and social capital } \\
\text { Environment } \\
\text { Institutional capital } \\
\text { Economy }\end{array}$ \\
\hline Kohl et al. [37] & Regional development & $\begin{array}{l}\text { Human capital } \\
\text { Structural capital } \\
\text { Relational capital }\end{array}$ \\
\hline
\end{tabular}

From Table 4, it may be pointed out that sustainability and competitive regional growth are the goals and some approaches already include environmental and social factors in their measurement frameworks. This demonstrates the tendency in intellectual capital theory to consider relevant global problems at the regional level. From Table 4, regional intellectual capital in this paper is defined as:(1) Human capital, including education, traditions and culture, and training and development; (2) structural capital, including governance, formal institutional environment, technology, capability for renewal, environment, and legislation; and (3) relational capital, including economic activity, market, societal framework, openness, and trust among regional actors. All these three dimensions of IC work together, creating synergy and a foundation for regional development. Conceptual relations between IC, regional competitiveness, and sustainable regional competitiveness are depicted below in Figure 1 .

From Figure 1, it can be interpreted that IC influences overall regional competitiveness as it is claimed by its definition [10-13]. However, sustainable regional competitiveness lays embedded in 
regional competitiveness and enriches it with additional dimensions as described in the previous subchapter. As Makarov [14] describes, sustainable regional competitiveness is achieved only when a certain level of "social-economic level of life" is attained. Therefore, it is important to explore basic factors influencing regional competitiveness together with the sustainable aspect of it.

\section{Factors Influencing Regional Competitiveness}

Regional competitiveness is an aspiration of every region. However, the achievement of this goal may not be as simple as it may seem. Every region is unique and has an embedded contextual situation, which cannot be neglected. Sometimes, learning from good practices or trying to replicate other regions' success ends up in failure or at least in a different outcome than was desired. There are many factors influencing regional competitiveness and they all are interrelated, creating a unique composition and leading to sustainable regional competitiveness. Therefore, it makes sense to present the main and basic factors influencing regional competitiveness and interpret which intellectual resources are associated in creating these factors (see Table 5).

Table 5. Factors influencing regional competitiveness (edited by authors).

\begin{tabular}{|c|c|c|c|}
\hline No. & Factor & Authors & Associated Intellectual Capital \\
\hline 1 & $\begin{array}{l}\text { Natural resources as } \\
\text { initial condition }\end{array}$ & Wang [41], OECD [42], Camagni \& Capello [43] & None \\
\hline 2 & $\begin{array}{l}\text { Innovative and } \\
\text { competitive industries }\end{array}$ & Porter $[44,45]$ & $\begin{array}{l}\text { Human capital } \\
\text { Structural capital } \\
\text { Relational capital }\end{array}$ \\
\hline 3 & Geographical features & Wang [41], Gallup et al. in [41] & None \\
\hline 4 & $\begin{array}{l}\text { Formal and informal } \\
\text { institutions }\end{array}$ & $\begin{array}{l}\text { North [46], David [47], OECD [42], Capello \& } \\
\text { Nijkamp [48], Rodríguez-Pose [49], Camagni \& } \\
\text { Capello [43], Pike et. al. [50] }\end{array}$ & Structural capital \\
\hline 5 & $\begin{array}{l}\text { Imposed vs. developed } \\
\text { institutions }\end{array}$ & Acemoglu \&Robinson [51] & Structural capital \\
\hline 6 & Decentralisation & OECD [52], Pike et. al. [50] & Structural capital \\
\hline 7 & $\begin{array}{l}\text { Spatial aggregation, } \\
\text { transportation } \\
\text { infrastructure }\end{array}$ & Wang [41], OECD [42], Camagni \& Capello [43] & None \\
\hline 8 & Human capital & $\begin{array}{l}\text { Wang [41], OECD [42], Florida et. al. [53], Capello \& } \\
\text { Nijkamp [48], Camagni \& Capello [43] }\end{array}$ & Human capital \\
\hline 9 & Path dependence & Wang [41], David [47], Martin \& Sunley [54] & $\begin{array}{l}\text { Structural capital } \\
\text { Human capital }\end{array}$ \\
\hline 10 & Market size & Wang [41], Diebolt \& Hippe [55] & Relational capital \\
\hline 11 & Economic integration & Wang [41], OECD [42] & $\begin{array}{l}\text { Structural capital } \\
\text { Relational capital }\end{array}$ \\
\hline 12 & Knowledge spill-overs & $\begin{array}{l}\text { Wang [41], OECD [42], Malecki [56], Capello \& } \\
\text { Nijkamp [48], Camagni \& Capello [43], } \\
\text { Pike et. al. [50] }\end{array}$ & Relational capital \\
\hline 13 & GDP spill-over & Wang [41] & None \\
\hline 14 & Good governance & OECD [42], Pike et. al. [50] & Structural capital \\
\hline 15 & Labour market & OECD [42] & Structural capital \\
\hline 16 & Entrepreneurial capital & $\begin{array}{l}\text { OECD [42], Baptista \& Leitao [57], Malecki [56], } \\
\text { Capello \& Nijkamp [48], Camagni \& Capello [43], } \\
\text { Huggins \& Williams [58], Cabrita et. al. [59] }\end{array}$ & $\begin{array}{l}\text { Human capital } \\
\text { Structural capital } \\
\text { Relational capital }\end{array}$ \\
\hline 17 & Agglomeration economy & $\begin{array}{l}\text { McCann \& van Oort in Capello \& Nijkamp [48], } \\
\text { Camagni \& Capello [43] }\end{array}$ & $\begin{array}{l}\text { Human capital } \\
\text { Structural capital } \\
\text { Relational capital }\end{array}$ \\
\hline 18 & Tourism potential & Pike et. al. [50] & None \\
\hline
\end{tabular}

Wang [41], the OECD (Organisation for Economic Co-operation and Development) [52], and Camagni and Capello [43] points out that natural resources as an initial condition can be the source of regional competitiveness. Some of the regions that have exclusive and valuable natural resources may create a competitive advantage in this field and compete with other regions in an international market. 
This factor is not associated with any of the intellectual resources. However, strategic management of natural resources and successful participation in a market requires all human, structural, and relational capital. However, if we look to natural resources solely as a factor for a competitive advantage, intellectual resources are not explored.

Porter $[44,45]$ has another attitude to regional competitiveness. First, he evaluates competitive industries and the resources required for their successful performance. This approach is known as Porter's diamond. It relies on four pillars: (1) Organizational strategy, structure and competition-these are internal conditions, which are managed by an organization's manager; (2) the actual conditions (qualified personnel, infrastructure, natural resources, etc.) - these are conditions that exist in a region and may be implemented for successful industrial performance; (3) demand conditions-Porter [44,45] claims that a fastidious and choosey market forces organizations to innovate and so keep up with competitors; and (4) related and supporting industries - this is a prerequisite condition for industries to thrive. There must be a particular ecosystem in a region where organizations can exist and flourish. The government, according to Porter [44,45], is a catalyst and challenger. It has a role to create a competitive environment for industries to evolve and create incentives for new businesses to start and to innovate for old ones. All intellectual capital dimensions are involved in these factors and create a particular intellectual capital composition, which reflects the environment and ecosystem in which business works.

Some authors [41] have excluded geographical features of a region as a factor for regional competitiveness. According to them, features, such as climate, relief, demography, or the environment, create initial preconditions for regional competitiveness to evolve. In this case, intellectual capital is not related or relevant. However, implementation of a particular strategy in order to create a competitive advantage based on these features may require intellectual resources as well.

Many authors distinguish formal and informal institutions as a competitive advantage precondition $[42,43,46-50]$. Formal institutions are normally associated with a regional legal base, which is a direct link to structural intellectual capital. These institutions define the rules of a "game" for market participants and may strongly influence their success or failure. Informal institutions are related to customs and manners that have evolved in a region, which are interpreted as "accepted norms of behaviour". It is hard to exclude typical intellectual capital form involved in this factor. It relates to human, structural, and relational capital. On the other hand, keeping in mind that this factor is usually interpreted in the context of trading deals, it is assumed that structural capital is the most important component. Formal and informal institutional changes arise from mental entrepreneurial models and the outside environment. In other words, entrepreneurs dictate formal and, especially, informal institutional changes. External stimuli strongly influence changes as well. Institutional changes and evolution of their directions are analysed by theory of path dependence [60].

Acemoglu and Robinson [51] explored imposed versus naturally evolved institutions' influence on regional competitiveness. According to the author, a naturally evolved institutional environment usually creates better competitive conditions compared to an imposed institutional structure. Imposed institutions typically seek benefits and profits for a third party. In addition, lacking the understanding of local people's needs, informal institutions may contradict with imposed institutions and so create an inefficient system. In this factor, structural intellectual capital is involved as discussed in the previous paragraph.

The OECD [52] and Pike et. al. [50] claim that decentralisation is one of the factors leading to regional competitiveness. That means that the higher autonomy of municipalities has a positive impact on regional competitiveness. It is the structural intellectual capital dimension because it defines how the government of a region is arranged.

Wang [41], OECD [42], and Camagni and Capello [43] have studied spatial regional aggregation and transport infrastructure's influence on competitiveness. They disclose that effective transportation and convenient spatial aggregation have a positive impact on competitiveness. Directly, no intellectual 
capital is involved in this factor. However, management and decision making on these issues requires human capital and a particular level of competence.

Many researchers agree that human capital is key to regional competitiveness $[41-43,48,53]$. This factor is a direct link to intellectual capital theory and approves the necessity of intellectual capital for regional competitiveness.

Some authors $[41,47,54]$ explain regional competitiveness based on path dependence theory. According to these authors, path dependence evolves through various factors: Natural resources' base; irretrievable local assets and infrastructure costs; industrial specialisation; regional technology lock-ins; agglomeration economy; regional institutions, social norms, and cultural heritage; and interregional relations and interdependencies [54]. Djelic and Quack [61] point out that in open systems, evolution paths change in a collision of internal and external paths. Mostly, this factor is associated with structural intellectual capital. However, a particular level of human capital may change the path if a critical mass of it is accumulated.

Market size is also excluded as one of the factors influencing regional competitiveness [41,55]. Market size may be determined by transport infrastructure's effectiveness. In addition, market accumulates human capital as well [62]. Market size is also defined by relations evolved in industries. Therefore, relational intellectual capital should be developed, in this case, improving collaboration between various parties in a region and outside of it.

Another important factor for regional competitiveness is economic integration [41,42]. This means that in regions, there should be an ensured free market, urbanised system, and eliminated trading barriers. Structural and relational capitals are involved in these factors.

Researchers draw attention to knowledge spill-overs or the knowledge sharing factor as a precondition for regional competitiveness [41-43,48,50,56]. It usually emerges through the development of close relationships among organizations and participation in knowledge and trading networks. In other words, in this case, networking has the main role. This is the relational capital component.

Wang [41] distinguishes regional GDP spill-over's influence on regional competitiveness. The author claims that external regional GDP changes relate to GDP changes in a particular region. This factor is not related to any intellectual capital component.

Good regional governance [42,50] and appropriate labour legislation [42] are also important factors influencing regional competitiveness. The governance role in regional competitiveness was mentioned in other researchers' works [44,45,50,52]. A particular governance model for a specific region depends on the local situation and already existing formal and informal institutions. Referring to [51], it is crucial that institutions evolve naturally rather than be copied or imposed blindly from outside. This factor is associated with structural intellectual capital as it defines the government and legal environment in a region.

Ref. $[43,48,52,56-58]$ name entrepreneurial capital as a factor for regional competitiveness. To enrich this capital, the business culture and supporting institutions are important as well as institutional barriers [63]. Entrepreneurial capital determines new start-ups' emergence in a region, adoption of brave and resolute actions, and willingness to take risks. This factor is influenced by all intellectual capital components and requires a particular empowering composition of them.

Another factor for regional competitiveness is an agglomeration economy [43,48]. Such an economy is typical for huge metropolitan economies. Usually, such competitiveness centres become capital regions, where the critical mass of human capital assembles, knowledge sharing among organizations easily takes place, and explicit trading and cooperation networks evolve. For this factor to be successful, all intellectual capital components are important.

Pike et. al. [50] also exclude tourism potential as a factor for regional competitiveness. This is true for regions, such as Cancun (Mexico) or Bali (Indonesia). However, not all regions can be proud of such popularity among tourists. Therefore, it would be inappropriate to count on this factor as a main 
factor in specific regions. This factor, even though it is not directly linked to intellectual capital, could be analysed to find the best ways to exploit this tourism potential.

From this analysis, it can be concluded that a lot of different factors influence regional competitiveness and that lays the foundation for more sustained development, with intellectual capital being associated to almost all aspects of it.

\section{Explaining the Intellectual Capital Interlink with Sustainable Regional Competitiveness}

The previous chapter demonstrates that intellectual capital has an important role in regional competitiveness and is involved in almost all factors influencing it. However, currently, the concept of competitiveness is shifting towards more sustainable growth, which is embedded in the overall development of a region. Therefore, it is necessary to talk about sustainable regional competitiveness, which includes more dimensions in addition to those presented above. Later, factors may be evaluated as the basic factors leading to regional competitiveness. However, sustainable regional competitiveness requires more than that (see Figure 1). Consequently, it makes sense to explore intellectual capital involvement in the set of factors defining sustainable regional competitiveness.

Based on the theoretical analysis in chapter 3, subchapter 2, factors defining sustainable regional competiveness are classified into five different categories. Intellectual capital's role is inseparable in all of them as discussed and presented below.

Intellectual capital is a major player and a foundation for sustainable regional competitiveness, as seen from Table 6. Human capital, structural capital, and relational capital can all be explored in the light of sustainability. Human capital development leads to a higher social awareness about social and ecological problems. People may be educated to cherish what they have and implement a more environmentally friendly lifestyle. As the Human Development Index presents, an increase in human capital increases life quality. Therefore, human capital development is one of the key resources for the overall competitiveness of a region. It is important for the competence pool in a region and creates a critical mass of knowledge that may change the institutional environment and break path dependence traits. Human capital is a foundation for the improvement of human lives because it brings the light of knowledge to a region. However, to take the best of human capital, other intellectual capital resources are required. Structural and relational capital empowers human capital to act and realize the potential hidden in a society and its people.

Table 6. Intellectual capital interlink with sustainable regional competitiveness (edited by authors).

\begin{tabular}{llllll}
\hline & $\begin{array}{c}\text { Environmental } \\
\text { Sustainability }\end{array}$ & $\begin{array}{c}\text { Social } \\
\text { Sustainability }\end{array}$ & Government & Infrastructure & $\begin{array}{c}\text { Investments and } \\
\text { Technology }\end{array}$ \\
\hline \multirow{3}{*}{ Associated IC } & $\begin{array}{l}\text { Structural capital } \\
\text { Human capital }\end{array}$ & $\begin{array}{l}\text { Human capital } \\
\text { Relational capital }\end{array}$ & Structural capital & $\begin{array}{l}\text { Structural capital } \\
\text { Human capital }\end{array}$ & $\begin{array}{l}\text { Human capital } \\
\text { Structural capital } \\
\text { Relational capital }\end{array}$ \\
\hline
\end{tabular}

Structural capital shapes the legal and institutional environment of a region. Regulations concerning environmental protection may be imbedded in regional policy and, as regional intellectual capital cases presented in theoretical background shows, some of the regions already include environmental capital in the IC framework. Structural capital also includes formal and informal institutions in a region. Therefore, social norms and the societal framework is shaped through this dimension of intellectual capital. A particular role is played by informal institutions, which define social interactions and accepted forms of behaviour. Social inclusion is embedded in these norms. They can be influenced and shaped by the government or media, which are structural capital forms. Media has a high impact in this situation and may change the traits of social norms. Media and government efficiency are included in the structural capital dimension of intellectual capital. Therefore, the development of it leads to better social and environmental policies and a higher awareness reached through education via media involvement in sustainable regional competitiveness. 
Relational capital defines interactions within various actors in a region. Public and private collaboration plays a crucial role in sustainable development. Consequently, relations among these two parties are a major factor in this field. The World Economic Forum [19] highlights the importance of private and public partnership in social and environmental sustainability. Accordingly, the government encourages green initiatives in the public sector through grants and financial support for organizations involved. The private sector may enrich the public sector with its knowledge and expertise that the public sector may lack. Universities collaborating with the private sector may create new green innovations and increase technological readiness for environmental sustainability. The World Economic Forum [19] claims that private-public collaboration may help to reach remote communities and deliver public services to even the most excluded areas. This partnership also may boost employment in remote regions through shared projects and increase urbanisation and basic services, such as mobile toilets or solar powered lighting. It is not hard to understand that collaboration between public organizations, universities, non-government organizations, and the private sector creates the highest value and can be realized through shared projects and initiatives. Public organizations and non-government organizations as well as universities could take a role of leaders and be initiators of the change. Leadership and entrepreneurial attitude is important from this point of view and should be encouraged in a region.

It can be concluded that intellectual capital plays an important role in sustainable regional competitiveness. It lays the foundation for long lasting sustainable regional growth. Faucheux [15] explored how intellectual capital and knowledge capital drives sustainable development in different levels: Local, national, regional, and global. Suciu and Năsulea [16] investigated intellectual capital and the creative economy as key drivers for competitiveness towards smart and sustainable development. Dal Mas [17] demonstrated the relationship between IC and sustainability through a practitioner's thoughts. This research supports the interlink between intellectual capital and sustainable regional competitiveness.

Efficient use of natural resources requires decent management of these resources and institutions determining regulations for pollution and emission. Structural capital is directly involved in an institutional framework. Development of human capital increases awareness and encourages society for increased care of the environment. Social capital is sometimes excluded as one of the dimensions of intellectual capital. Therefore, it is directly involved in social sustainability. Human capital development plays the main role in this part. It can be defined through the human development index, which describes the expected life quality of people. Relational capital is also crucial for social cohesion and overall social well-being. Government efficiency is one of the key indicators of the structural capital of a region. Legislation and formal and informal institutions dictated by the government define the strategy and attitude of a region towards sustainable development. The government may be understood as a leader and initiator of sustainable movement in a region. Intangible infrastructure is one of the indicators of structural capital. Even though tangible infrastructure as transportation or spatial aggregation is explored in intellectual capital theory, it remains limited, and higher human awareness influences sustainable decision making in this field [40]. Therefore, society's education on sustainability should be considered in this area. Innovation, smart specialisation, public-private collaboration-all include intellectual capital as a foundation for technological development. Sometimes, innovation or renewable capital is excluded as a separate dimension of intellectual capital. Hence, this factor is directly linked to regional intellectual capital.

\section{Discussion}

Regional competitiveness is defined by many factors that interplay and only the combination of these factors creates long lasting and sustainable competitiveness in the future. Sustainable regional competitiveness is a concept that is still not defined fully. This leaves a lot of freedom to interpret it in different ways. A sustainable competitive advantage may be achieved through basic factors influencing competitiveness, but that does not mean that better lives for future generations will be 
guaranteed. We need a new definition of sustainable regional competitiveness and it may be achieved through integration of sustainability features of competitive growth. In this paper, the factors that influence regional competitiveness and how intellectual capital is involved in these factors were analysed. Intellectual capital involvement in the factors defining sustainable regional competitiveness was also considered. However, it is only a deliberation because sustainable regional competitiveness is still vaguely defined.

Intellectual capital is believed to be a foundation for the future growth and wealth of a region. It can be observed that intellectual capital participates in almost all aspects of competitiveness, including factors of sustainability. In the context of sustainability, intellectual capital plays an even more important role. It defines the sophistication of a region and the awareness of global problems that must be addressed considering regional development. Therefore, the development of intellectual capital is a necessity for sustainable regional growth as it helps to educate people and encourage a more sustained lifestyle.

However, whether sustainability is a concern in all regions is a worthy consideration. Current tendencies show that more developed countries tend to focus towards sustainable development and bothers other global issues [4]. It may seem obvious, keeping in mind that underdeveloped countries have more important issues than sustainability. They care about survival, not about the future of the next generations. This leads to the consideration that the basic factors of competitiveness presented in Table 5 are more important to developing countries and sustainability becomes a concern after a certain level of competitiveness is achieved. It may be considered that factors in Table 5 are a foundation for competitiveness and lay the potential for future development. This conceptual interpretation is depicted in Figure 1. However, sustainable regional competitiveness is the next level that is achievable after the initial development phase [14]. On the other hand, even some developed countries, like the USA, rank conditionally low in the sustainable competitiveness index [4]. This leads to the consideration what actually drives the attitude towards sustainable development. One of the theories may be that the government viewpoint defines the path the country takes. However, there are other factors, like society's position and awareness. Bardy et. al. [64] researched intellectual capital development in a rural community of Northern Ghana to achieve sustainable development. This research demonstrated that IC can become the foundation for sustainability even in underdeveloped communities if managed correctly. It can be concluded that it is still unclear what the drivers of sustainability are and why one region chooses to take a sustainable growth path while others care about this less.

Nevertheless, intellectual capital development may be considered as a catalyst for underdeveloped regions to boost their growth. As a study of Arab countries shows [11], intellectual capital is a foundation for developing countries to reach higher standards of living. Many intellectual capital studies have proven the relationship between intellectual capital and GDP, and in developing countries, human capital development has the highest impact. This may lead to the hypothesis that investments in intellectual capital may encourage not only competitive regional growth, but sustainable regional growth as well.

\section{Conclusions}

Sustainability is a concept explored in the literature more and more. It is already realised that regional development should be achieved without contradicting the growth of future generations. Environmental and social issues must be addressed regarding competitive regional development. Therefore, in this paper, not only were the basic factors influencing regional competitiveness explored, but also the factors that define sustainable regional competitiveness. A conceptual interpretation of relations between IC, regional competitiveness, and sustainable regional competitiveness was provided in Figure 1.

Intellectual capital, defined as the foundation for long lasting growth and the well-being of a region, was chosen as the basis for the analysis carried out in this paper. As the results show, intellectual 
capital plays an important role in regional competitiveness and is even more important concerning sustainable regional competitiveness. It raises an awareness of society about sustainability, defines the legal and institutional environment of a region, expresses the relations between various stakeholders, and together creates the foundation for a sustainable competitive advantage.

Factors influencing regional competitiveness were defined from the literature review and 18 factors were defined. Together, these create the basic requirements for competitive growth and they all interact with each other. However, the empowerment of them and realization of the potential hidden in these factors requires intellectual capital. Intellectual capital can be described as a major pillar, which holds a key to unleash the capacity of these factors.

How sustainable regional competitiveness could be defined was also explored, and the main factors were drawn out. Three different frameworks were analysed: The World Economic Forum framework, the Global Sustainable Competitiveness Index, and the Global Green Economy Index. The main features of sustainable regional competitiveness were defined through five dimensions: (1) Environmental sustainability, (2) social sustainability, (3) government, (4) infrastructure, and (5) investments and technology. How intellectual capital is involved in all these five dimensions was also explored and it can be concluded that intellectual capital plays a crucial role in all these aspects. Intellectual capital is required for the efficient use of natural resources and regulations that define environmental sustainability. Social capital is sometimes excluded as a separate dimension of intellectual capital and this demonstrates that it is directly linked to social sustainability. Government efficiency is a structural capital indicator and defines the leadership level embedded in a region. Entrepreneurial capital, which is also a dimension of intellectual capital, is also important because it reflects a region's attitude towards new decisions and risk taking, and shapes the informal institutional environment. Higher human sophistication leads towards more sustainable decisions on tangible infrastructure development. Green innovations and shared projects between different parties in a region cannot be actualized without intellectual capital as well.

Therefore, it is concluded in this paper that sustainable regional competitiveness cannot be achieved without proper implementation and development of intellectual capital. The main contribution of the paper is the demonstrated interlink between IC, regional competitiveness, and sustainability as well as the revealed relation between IC and sustainable regional competitiveness.

\section{Limitations and Future Research}

The paper was based on a qualitative judgment of the interlink between intellectual capital and sustainable regional competitiveness. The later concept is so far not widely defined and therefore the interpretation provided in this paper can be argued. Regional intellectual capital is also a broad concept and the provided definition may include limitations on how it is understood. Chapter 4 is based on 19 papers, which could have led to missing some factors. To prevent this, the research was carried out until the factors started to repeat. However, there is still a possibility something was missed. For future research, a further analysis of the concepts of sustainable regional competitiveness and intellectual capital is recommended to provide more rigorous interlinks between these two. Currently, sustainable competitiveness is interpreted as long term competitiveness or socially and environmentally friendly development. Therefore, this paper explores both understandings, but it must be clarified for improved results in the future.

Author Contributions: Conceptualization, V.J. and L.U.; methodology, V.J.; formal analysis, V.J.; investigation, V.J; writing—original draft preparation, V.J.; writing—review and editing, V.J. and L.U.; visualization, V.J.; supervision, L.U.; project administration, V.J. and L.U.

Funding: This research received no external funding.

Conflicts of Interest: The authors declare no conflict of interest. 


\section{References}

1. Henderson, H. Worldwide support found for measuring true wealth of nations. Foresight 2008, 10, 67-69. [CrossRef]

2. Delgado, M.; Ketels, C.; Porter, M.E.; Stern, S. The Determinants of National Competitiveness; National Bureau of Economic Research: Cambridge, UK, 2012.

3. World Economic Forum. The Global Competitiveness Report the Global Competitiveness Report; World Economic Forum: Geneva, Switzerland, 2015.

4. SolAbility. The Sustainable Competitiveness Report, 6th ed.; SolAbility Sustainable Intelligence: Zurich, Switzerland; Seoul, Korea, 2017.

5. World Commission on Environment and Development's (the Brundtland Commission's). Our Common Future; Oxford University Press: Oxford, UK, 1987.

6. European Union. Regional Innovation Scoreboard 2017; European Innovation Scoreboards (EIS) Project for the European Commission, Directorate-General for Internal Market, Industry, Entrepreneurship and SMEs; European Union: Brussels, Belgium, 2017.

7. Guthrie, J. The management, measurement and the reporting of intellectual capital. J. Intellect. Cap. 2001, 2, 27-41. [CrossRef]

8. Zickgraf, S. tellectual Capital Statement-Made in Europe (InCaS); DG Research under the EU 6th Framework Programme; Confédération Européenne Des Associations De Petites Et Moyennes Entreprises: Brussels, Belgium, 2009.

9. Roos, G.; Pike, S.; Ferntröm, L. Managing Intellectual Capital in Practice; Elsevier: Oxford, UK, 2005.

10. Edvinsson, L.; Stenfelt, C. Journal of Human Resource Costing \& Accounting. J. Hum. Resour. Cost. Account. 1999, 4, 21-33.

11. Bontis, N. National Intellectual Capital Index: A United Nations initiative for the Arab region. J. Intellect. Cap. 2004, 5, 13-39. [CrossRef]

12. Lin, C.Y.-Y.; Edvinsson, L. National intellectual capital: Comparison of the Nordic countries. J. Intellect. Cap. 2008, 9, 525-545.

13. Schiuma, G.; Lerro, A.; Carlucci, D. The Knoware Tree and the Regional Intellectual Capital Index: An assessment within Italy. J. Intellect. Cap. 2008, 9, 283-300. [CrossRef]

14. Makarov, P. Intellectual Capital as an Indicator of a Sustainable Development. J. Sustain. Dev. 2010, 3, 85-90. [CrossRef]

15. Faucheux, S. Intellectual and knowledge capital for sustainable development at local, national, regional, and global levels. In Social and Economic Development; del Campo, S., Hamada, T., Barbiroli, G., Sassen, S., Barbieri-Masini, E., Nkwi, P.N., Sichone, O., Momoh, A., Eds.; EOLSS Publishers: Paris, France, 2010; Volume 1, pp. 89-115.

16. Suciu, M.C.; Năsulea, D.F. Intellectual Capital and Creative Economy as Key Drivers for Competitiveness Towards a Smart and Sustainable Development: Challenges and Opportunities for Cultural and Creative Communities. In Intellectual Capital Management as a Driver of Sustainability; Matos, F., Vairinhos, V., Selig, P., Edvinsson, L., Eds.; Springer: Cham, Switzerland, 2019.

17. Dal Mas, F. The Relationship between Intellectual Capital and Sustainability: An Analysis of Practitioner's Thought. In Intellectual Capital Management as a Driver of Sustainability; Matos, F., Vairinhos, V., Selig, P., Edvinsson, L., Eds.; Springer: Cham, Switzerland, 2019.

18. European Union. European Competitiveness Report 2009; Publications Office of the European Union: Luxembourg, 2010.

19. World Economic Forum. Assessing the Sustainable Competitiveness of Nations. In The Global Competitiveness Report 2013-2014; World Economic Forum: Geneva, Switzerland, 2013; pp. 53-82.

20. Dual Citizen LLC. The Global Green Economy Index 2018; Dual Citizen LLC: New York, NY, USA, 2018.

21. Käpylä, J. Towards a critical societal knowledge management. J. Intellect. Cap. 2012, 13, 288-304. [CrossRef]

22. Weziak, D. Measurement of National Intellectual Capital: Application to EU Countries; IRISS Working Paper Series No. 13; INSEAD: Luxembourg, 2007.

23. Andriessen, D.G.; Stam, C.D. Intellectual capital of the European Union. In McMaster World Congress on the Management of Intellectual Capital and Innovation; De Baak: Diemen, Netherlands, 2005; pp. 1-24. 
24. Lin, C.Y.Y.; Edvinsson, L. National Intellectual Capital, A Comparison of 40 Countries; Springer: New York, NY, USA, 2011.

25. Salonius, H.; Lönnqvist, A. Exploring the policy relevance of national intellectual capital information. J. Intellect. Cap. 2012, 13, 331-342. [CrossRef]

26. Chaminade, C.; Johanson, U. Can guidelines for intellectual capital management and reporting be considered without addressing cultural differences? J. Intellect. Cap. 2003, 4, 528-542. [CrossRef]

27. Angel Axtle Ortiz, M. Analysis and valuation of intellectual capital according to its context. J. Intellect. Cap. 2009, 10, 451-482. [CrossRef]

28. Kujansivu, P. Intellectual Capital Management-Understanding Why Finnish Companies Do Not Apply Intellectual Capital Management Models; Publication 747; Tampere University of Technology: Tampere, Finland, 2008.

29. Lönnqvist, A.; Kianto, A.; Sillanpää, V. Using intellectual capital management for facilitating organizational change. J. Intellect. Cap. 2009, 10, 559-572. [CrossRef]

30. Yigitcanlar, T.; Lönnqvist, A. Benchmarking knowledge-based urban development performance: Results from the international comparison of Helsinki. J. CITIES 2012, 31, 357-369. [CrossRef]

31. Malhotra, Y. Measuring Knowledge Assets of a Nation: Knowledge Systems for Development; United Nations: New York, NY, USA, 2003.

32. Schneider, U. The Austrian National Knowledge Report. J. Knowl. Manag. 2007, 11, 129-140. [CrossRef]

33. Käpylä, J.; Kujansivu, P.; Lönnqvist, A. National intellectual capital performance: A strategic approach. J. Intellect. Cap. 2012, 13, 343-362. [CrossRef]

34. Medina, A.J.S.; Gonzalez, A.M.; Falcon, J.M.G. Intellectual capital and sustainable development on islands: An application to the case of Gran Canaria. Reg. Stud. 2007, 41, 473-487. [CrossRef]

35. Lerro, A.; Schiuma, G. Knowledge-based dynamics of regional development: The case of Basilicata region. J. Knowl. Manag. 2009, 13, 287-300. [CrossRef]

36. Lönnqvist, A.; Käpylä, J.; Salonius, H.; Yigitcanlar, T. Knowledge That Matters: Identifying Regional Knowledge Assets of the Tampere Region Knowledge That Matters: Identifying Regional Knowledge Assets of the Tampere Region. Eur. Plan. Stud. 2014, 22, 2011-2029. [CrossRef]

37. Kohl, H.; Wuscher, S.; Orth, R.; Steinhöfel, E. Intellectual Capital Statements as a Driver for Regional Development. In Proceedings of the European Conference on Intellectual Capital; Academic Conferences Limited, Sonning Common, UK, 9-10 April 2015; pp. 189-198.

38. Rodriguez, B.M.; Viedma Martí, J.M. The region's intellectual capital benchmarking system: Enabling economic growth through evaluation. J. Knowl. Manag. 2006, 10, 41-54. [CrossRef]

39. Kozak, M. Strategic approach to intellectual capital development in regions. Int. J. Learn. Intellect. Cap. 2011, 8, 76-93. [CrossRef]

40. Yigitcanlar, T.; Lönnqvist, A.; Salonius, H. Analysis of a city-region from the knowledge perspective: Tampere, Finland. Vine 2014, 44, 445-466. [CrossRef]

41. Wang, Z. Principles of Regional Science; Springer: Singapore, 2017.

42. OECD. OECD Regional Outlook 2016: Productive Regions for Inclusive Societies; OECD: Paris, France, 2016.

43. Camagni, R.; Capello, R. Regional Competitiveness and Territorial Capital: A Conceptual Approach and Empirical Evidence from the European Union. Reg. Stud. 2013, 47, 1383-1402. [CrossRef]

44. Porter, M.E. The Competitive Advantage of Nations. Harvard Business Review. March-April 1990, pp. 73-91. Available online: https://s3.amazonaws.com/academia.edu.documents/34289003/ CompetitiveAdvantageOfNations.pdf?AWSAccessKeyId=AKIAIWOWYYGZ2Y53UL3A\&Expires= 1545194721\&Signature=PATEZUWfaHTNY793z2qQgJ86BbI\%3D\&response-content-disposition=inline\% 3B\%20filename\%3DThe_Competitive_Advantage_of_Nations.pdf (accessed on 19 November 2018).

45. Porter, M.E. New global strategies for competitive advantage. Plan. Rev. 1990, 18, 4-14. [CrossRef]

46. North, D.C. Institutions, Institutional Change and Economic Performance; Cambridge University Press: Cambridge, UK, 1990.

47. David, P.A. Why are institutions the "carriers of history"? Path dependence and the evolution of conventions, organizations and institutions. Struct. Chang. Econ. Dyn. 1994, 5, 205-220. [CrossRef]

48. Capello, R.; Nijkamp, P. Handbook of Regional Growth and Development Theories; Edward Elgar: Cheltenham/Northampton, UK, 2009.

49. Rodríguez-Pose, A. Do Institutions Matter for Regional Development? Reg. Stud. 2013, 47, $1034-1047$. [CrossRef] 
50. Pike, A.; Rodríguez-Pose, A.; Tomanay, J. Local and Regional Development; Routledge: Abingdon, UK; New York, NY, USA, 2006.

51. Acemoglu, D.; Robinson, J.A. Why Nations Fail: The Origins of Power, Prosperity and Poverty; Crown Publishers: New York, NY, USA, 2012.

52. OECD. Regional Development Policies in OECD Countries; OECD: Paris, France, 2010.

53. Florida, R.; Mellander, C.; Stolarick, K. Inside the black box of regional development-Human capital, the creative class and tolerance. J. Econ. Geogr. 2008, 8, 615-649. [CrossRef]

54. Martin, R.; Sunley, P. Path dependence and regional economic evolution. J. Econ. Geogr. 2006, 6, $395-437$. [CrossRef]

55. Diebolt, C.; Hippe, R. Remoteness equals backwardness? Human capital and market access in the European regions: Insights from the long run. Educ. Econ. 2018, 26, 285-304. [CrossRef]

56. Malecki, E.J. Technology and Economic Development: The Dynamics of Local, Regional, and National Change; University of Illinois at Urbana-Champaign's Academy for Entrepreneurial Leadership Historical Research Reference in Entrepreneurship; Longman: Essex, England, 1997.

57. Baptista, R.; Leitao, J. Entrepreneurship, Human Capital and Regional Development: Labor Networks, Knowledge Flows and Industry Growth; Springer: New York, NY, USA, 2015.

58. Huggins, R.; Williams, N. Entrepreneurship and regional competitiveness: The role and progression of policy. Entrepreneurship Reg. Dev. 2011, 23, 907-932. [CrossRef]

59. Cabrita, M.R.; Cabrita, C.; Matos, F.; Dueñas, M.D.P.M. Entrepreneurship Capital and Regional Development: A Perspective Based on Intellectual Capital. In Entrepreneurship, Human Capital and Regional Development: Labor Networks, Knowledge Flows and Industry Growth; Baptista, R., Leitao, J., Eds.; Springer: New York, NY, USA, 2015.

60. Sjöstrand, S.E. Institutional Change: Theory and Empirical Findings; M. E. Sharp: New York, NY, USA, 1993.

61. Djelic, M.L.; Quack, S. Overcoming path dependency: Path generation in open systems. Theory Soc. 2007, 36, 161-186. [CrossRef]

62. Redding, S.; Schott, P. Distance, Skill Deepening and Development: Will Peripheral Countries Ever Get Rich? J. Dev. Econ. 2003, 72, 515-541. [CrossRef]

63. Audretsch, D.; Monsen, E. Entrepreneurship capital: A regional, organizational, team and individual phenomenon. In International Handbook of HRM and Entrepreneurship; Mayson, S., Barrett, R., Eds.; Edward Elgar: Cheltenham, UK, 2008.

64. Bardy, R.; Rubens, A.; Eberle, P. Building Intellectual Capital for Sustainable Development: Combining Local Wisdom and Advanced Knowledge. Electron. J. Knowl. Manag. 2017, 15, 159-169. Available online: www.ejkm.com (accessed on 10 December 2018). 